\title{
Assessment of endothelial cell density and corneal thickness in corneal grafts an average of 5 years after penetrating keratoplasty
}

\author{
Beata Kettesy · Gabor Nemeth · Adam Kemeny-Beke · Andras Berta · Laszlo Modis
}

Received: 22 October 2013 / Accepted: 8 February 2014

(C) Springer-Verlag Wien 2014

\begin{abstract}
Summary
Background Corneal transparency is a useful indicator for corneal function. Our aim was to investigate central corneal endothelial cells and corneal thickness in transplanted corneas at an average of 5.4 years after penetrating keratoplasty

Patients and methods The study involved 68 perforated keratoplasty patients with at least a 1 year followup. Post-operatively, the central corneal endothelial layer was observed using a contact specular microscope. Central endothelial cell density, corneal thickness and the coefficient of variation of endothelial size were statistically analysed.

Results The post-operative follow-up time was ranging from 12 months to 23 years. Endothelial cell density (ECD) was $1,501 \pm 249 \mathrm{cell} / \mathrm{mm}^{2}$. The average cell size was $673.6 \pm 98.3 \mu \mathrm{m}^{2}$, and the coefficient of variation of cell size was $0.61 \pm 0.11$. No difference in ECD was detected between diagnostic groups. Corneal thickness was $0.56 \pm 0.06 \mathrm{~mm}$. Correlation between ECD and post-operative time was not significant $(r=0.02 ; p=0.85)$.

Conclusion Our study concluded that ECD showed a higher rate of decrease after penetrating keratoplasty with no relation to pre-operative diagnosis.
\end{abstract}

Keywords Endothelial cell loss · graft survival · penetrating keratoplasty $\cdot$ specular microscope

B. Kettesy, MD $(\varangle) \cdot G$. Nemeth, MD, PhD .

A. Kemeny-Beke, MD, PhD · A. Berta, MD, PhD, DSc .

L. Modis Jr., MD, PhD, DSc

Department of Ophthalmology,

Medical Health and Science Center, University of Debrecen,

Nagyerdeikrt. 98, 4032 Debrecen, Hungary

e-mail: kettesyb@freemail.hu
Bestimmung der Endothelzelldichte und der Hornhautdicke in Hornhauttransplantaten circa 5 Jahre nach einer penetrierenden Keratoplastik

\section{Zusammenfassung}

Hintergrund Die Transparenz der Cornea ist ein nützlicher Indikator der Funktion der Hornhaut. Das Ziel unserer Studie war es, die zentralen Endothelzellen der Cornea sowie die Dicke der Hornhaut in transplantierten Hornhäuten circa 5,4 (im Durchschnitt) Jahre nach penetrierender Keratoplastik zu untersuchen.

Patienten und Methoden In die Studie wurden 68 Patienten nach perforierter Keratoplastik aufgenommen, die zumindest 1 Jahr nachuntersucht worden waren. Postoperativ wurde die zentrale Endothelschicht der Hornhautmittel seines Kontakt-Spekular Mikroskops untersucht. Die Dichte der zentralen Endothelzellen, die Dicke der Hornhaut und der Variations-Koeffizient der Größe des Endothels wurden statistisch analysiert.

Ergebnisse Der Zeitpunkt der postoperativen Kontrollen variierte von 12 Monaten bis 23 Jahren. Die Endothelzelldichte (EZD) lag bei $1501 \pm 249$ Zelle $/ \mathrm{mm}^{2}$. Der Mittelwert der Zellgröße war 673,6 $\pm 98,3 \mu \mathrm{m}^{2}$ und der Variationskoeffizient $0,61 \pm 0,11$. Es gab keinen Unterschied in der EZD zwischen den nach Diagnosen eingeteilten Gruppen. Die Korrelation zwischen der EZD und dem Zeitabstand zur Operation war nicht kant $(r=0,02$; $p=0,85)$.

Schlussfolgerung Unsere Studie zeigt unabhängig von der präoperativen Diagnose eine abfallende Tendenz der EZD nach penetrierender Keratoplastik.

Schlüsselwörter Endothelzellverlust · Graft Überleben · penetrierende Keratoplastik · Spekular Mikroskop 


\section{Introduction}

Penetrating keratoplasty (PKP) has become the most frequently employed allograft surgery [1]. The long-lasting optical clarity of the cornea after PKP is considerably determined by the number, the morphology and the function of donor endothelial cells. The morphology of corneal endothelial cells can be evaluated by specular microscopy. In our study, the morphology of the donors' central corneal endothelial cell has been traced for an average of 5.4 years after PKP to assess the longevity of the transplanted grafts. Relatively few reports have been made to study at least 5-year-graft survival including detailed donor endothelial data as is present in our study [2-9].

\section{Patients and methods}

A total of 68 post-keratoplastic patients were subject to our investigations at least 1 year after PKP. Causative diagnosis were keratoconus $(n=36)$, bullous keratopathy $(n=14)$, corneal leucoma $(n=9)$, herpetic keratitis $(n=7)$, acanthamoeba keratitis $(n=1)$ or corneal dystrophy $(n=1)$.

In all, 29 of the donor corneas were preserved in Optisol corneal storage medium (Chiron Ophthalmics, Irvine, California), and 39 were stored in a moist chamber. The donor corneal grafts were between 6.5 and $7.5 \mathrm{~mm}$ in diameter. The recipients' corneas were between 6.0 and $7.0 \mathrm{~mm}$ in diameter. The grafts were sutured using a 16-bit 10-0 nylon running suture.

The parameters of donor endothelial cell were detected at an average of 67.8 months post-operatively (ranging from 12 months to 23 years). Patients with a history of contact lens wear were excluded from this study. At follow-up visits, after using tetracaine hydrochloride as topical anaesthesia, central corneal endothelial photographs were taken of three different central areas of the recommended sample size of 50-100 cells with a contact specular microscope (EM 1200, Tomey, Tennenlohe, Germany) [2-4]. The mean central endothelial cell density (ECD) and the coefficient of variation of endothelial cell size describing polymegethism were calculated with the built-in image analysis software (v. 1.5.1) of the device. Regarding corneal thickness, the normalized magnification conversion table provided by the manufacturer was used to ensure an accurate cell density. The annual endothelial cell loss was calculated from the preand post-operative cell density. All data were assessed in relation to the pre-operative diagnosis and the type of preservation. All procedures adhered to the tenets of the Declaration of Helsinki and approved by local ethics committee. All participants provided informed consent about the examinations.

Statistical analysis was performed using SPSS 13.0 software (SPSS Inc., Chicago, Illinois, USA) and data were described in terms of mean \pm standard deviation (SD), coefficient of variation (SD/mean) and range. Dif- ferences between groups were recorded using the paired test of Wilcoxon, and a $p$-value of 0.05 was considered as the level of significance. Associations between groups were established with Spearman's correlation of rho (r).

\section{Results}

At all follow-up visits each transplanted cornea was clear at slit-lamp examinations. At examination time, recipient patients' mean age was $42.4 \pm 17.1$ years. The mean age of donors was $66.2 \pm 14.3$ years. The average post-operative follow-up time was $67.8 \pm 74.1$ months (ranging from 12 to 276 months).

Endothelial parameters were counted in three different central donor corneal areas of $80.3 \pm 34$ cell/ $\mathrm{mm}^{2}$ each. At examination time, the overall ECD was $1,501 \pm 249 \mathrm{cell} / \mathrm{mm}^{2}$ (ranging from 1,100 to $2,225 \mathrm{cell} /$ $\mathrm{mm}^{2}$; Figs. 1 and 2). In the keratoconus group, it was $1,483 \pm 244 \mathrm{cell} / \mathrm{mm}^{2}$, in the bullous keratopathy group $1,528 \pm 279 \mathrm{cell} / \mathrm{mm}^{2}$, in the herpetic keratitis group $1,573 \pm 263 \mathrm{cell} / \mathrm{mm}^{2}$, and in the leucoma group $1,509 \pm 334 \mathrm{cell} / \mathrm{mm}^{2}$. No difference in ECD was detected between the keratoconus group and bullous keratopathy $(p=0.58)$, herpetic keratitis $(p=0.42)$ or leucoma ( $p=0.82)$ groups. The average ECD was $1,545 \pm 237$ cell/ $\mathrm{mm}^{2}$ in the preserved group and $1,467 \pm 256 \mathrm{cell} / \mathrm{mm}^{2}$ in the moist chamber group ( $p=0.2), 5.4$ years after PKP. The average cell size was $665.4 \pm 118.8 \mu \mathrm{m}^{2}$ (ranging from 447.5 to $915.5 \mu \mathrm{m}^{2}$ ), and the coefficient of variation of cell size was $0.61 \pm 0.11$ (ranging from 0.37 to 0.85 ). Corneal thickness was $0.56 \pm 0.06 \mathrm{~mm}$ (ranging from 0.45 to $0.73 \mathrm{~mm}$ ). We can observe a statistically significant positive correlation between post-operative time and corneal thickness $(r=0.36, p=0.002)$.
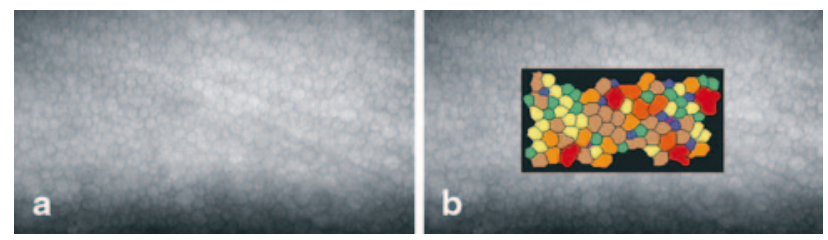

Fig. 1 Endothelial image analysis made by the contact specular microscope $(\mathbf{a}, \mathbf{b})$. Number of cells counted-86 cells, endothelial cell density $-2,300$ cells $/ \mathrm{mm}^{2}$, average cell size$431 \mu \mathrm{m}^{2}$ and coefficient of variation of the cell area -0.46
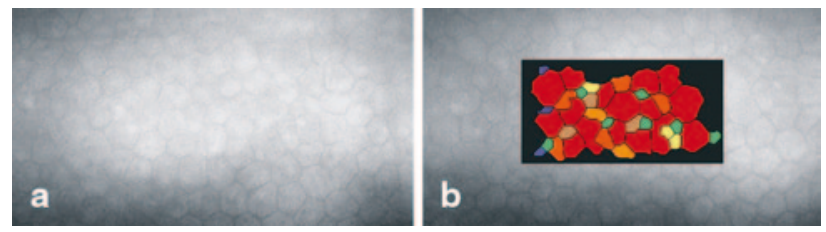

Fig. 2 Endothelial image analysis made by the contact specular microscope (a, b). Number of cells counted -54 cells, endothelial cell density $-1,600$ cells $/ \mathrm{mm}^{2}$, average cell size$616 \mu \mathrm{m}^{2}$ and coefficient of variation of the cell area -0.71 
Correlation between ECD and post-operative time was $r=0.02(p=0.85)$. At examination time, there was no significant correlation between patient's age and ECD $(r=0.11, p=0.35)$. The rate of endothelial cell loss was $15.8 \%$ per year in the first 2 years in the preserved group.

The coefficient of variation of cell size was $0.61 \pm 0.11$ (ranging from 0.37 to 0.85 ). The mean endothelial cell size was $673.6 \pm 98.3 \mu \mathrm{m}^{2}$ (ranging from 447.5 to $915.5 \mu \mathrm{m}^{2}$ ). Corneal thickness was $0.56 \pm 0.06 \mathrm{~mm}$ (ranging from 0.45 to $0.73 \mathrm{~mm}$ ) and was measured with a contact specular microscope (Table 1). No significant correlation was found between ECD recipient $(r=0.11 ; p=0.35)$ or donor age $(r=0.04 ; p=0.83)$. There was no correlation between coefficient of variation of cell size and post-operative time $(r=-0.01, p=0.92)$ and between ECD and corneal thickness $(r=0.01, p=0.92)$.

\section{Discussion}

PKP was the most frequently employed allograft transplantation surgery [1]. Pseudophakic bullous keratopa- thy, Fuch's dystrophy, keratoconus, corneal scarring and aphakic bullous keratopathy $[3,5,7]$ are considered to be main indications for PKP.

Different studies on PKP have reported that the 1-year survival rate of donor cornea is up to $90 \%$, at 5 years it is $88 \%$, at 10 years it is $80 \%$ and in the 2007 Australian graft report it is $60 \%$ [10-12]. Graft clarity rate can reach the extent of $97 \%$ after 4 years in the low-risk group [13]. In transplanted corneas, endothelium can keep its function in some cases even for 30 years [14-17], with an initial cell density above 2,500 cells $/ \mathrm{mm}^{2}$ (Table 2 ). Minimal cell density at the time of PKP is reported to range between 2,000 and 2,500 cells $/ \mathrm{mm}^{2}$ and the minimal, critical cell density limit for corneal decompensation is 250-500 cells $/ \mathrm{mm}^{2}[14,15,18-21]$. Donor corneas with initial cell densities under 2,000 cells $/ \mathrm{mm}^{2}$ could reach this critical cell density in less than 20 years [8]. In normal eyes, the half-time for the slow component of ECD loss due to ageing is 224 years, which is decreasing to 21-26 years after intraocular surgeries [16].

In our study, corneal endothelium of 68 eyes with an optically clear donor cornea at slit lamp examinations

Table 1 Endothelial cell density (ECD), average cell size, coefficient of variation (CV) of cell size and corneal thickness data in our different causative diagnostic groups for perforating keratoplasty

\begin{tabular}{|l|l|l|l|l|}
\hline & ECD $\left(\right.$ cell/ $\left./ \mathrm{mm}^{2}\right)$ & Average cell size $\left(\mathrm{mm}^{2}\right)$ & CV of cell size & \multicolumn{1}{c|}{ Corneal thickness $(\mathrm{mm})$} \\
\hline Keratoconus & $1,483 \pm 244$ & $644.8 \pm 114.3$ & $0.62 \pm 0.4$ & $0.56 \pm 0.07$ \\
\hline Bullous keratopathy & $1,528 \pm 279$ & $692.4 \pm 111.9$ & $0.61 \pm 0.3$ & $0.57 \pm 0.04$ \\
\hline Corneal leucoma & $1,509 \pm 334$ & $658.5 \pm 110.2$ & $0.60 \pm 0.4$ & $0.58 \pm 0.07$ \\
\hline Herpetic keratitis & $1,573 \pm 263$ & $616.2 \pm 77.1$ & $0.59 \pm 0.4$ & $0.54 \pm 0.04$ \\
\hline Acanthamoebakeratitis & $1,446.6$ & 665.3 & 0.45 & 0.51 \\
\hline Corneal dystrophy & $1,668.5$ & 611.3 & 0.42 & 0.50 \\
\hline
\end{tabular}

Table 2 Donor corneal endothelial cell loss after penetrating keratoplasty in various studies

\begin{tabular}{|l|l|l|l|}
\hline Reference & Mean post-operative time (years) & ECD loss (\%) & ECD at post-operative time (cells/mm²) \\
\hline Linn et al. [2] & $1-10$ & $50 \%$ per 10 years & $502-1,708$ \\
\hline Linn et al. [2] & 20 & & $682-1,708$ \\
\hline Abott et al. [35] & 17.4 & $52 \pm 19 \%$ compared with the initial number & $1,418 \pm 600$ \\
\hline Bourne et al. [37] & 3 & $59 \pm 17 \%$ compared with the initial number & $1,214 \pm 533$ \\
\hline Bourne et al. [37] & 5 & $34 \pm 22 \%$ compared with the initial number & $1,958 \pm 718$ \\
\hline Ing et al. [5] & 1 & $53 \pm 19 \%$ compared with the initial number & $1,376 \pm 86$ \\
\hline Ing et al. [5] & 3 & $67 \pm 17 \%$ compared with the initial number & $960 \pm 470$ \\
\hline Ing et al. [5] & 10 & & $808 \pm 194$ \\
\hline Kus et al. [6] & $22 \pm 6$ & $9.5 \%$ per year & $1,751 \pm 605$ \\
\hline Langenbucher et al. [40] & 2 & $53 \pm 19 \%$ & $1,376 \pm 586$ \\
\hline Bourne [8] & 3 & $59 \pm 17 \%$ & $1,191 \pm 523$ \\
\hline Bourne [8] & 5 & $72 \pm 10 \%$ & $850 \pm 237$ \\
\hline Bourne [8] & 15 & $12.1 \pm 16.3$ & $998 \pm 343$ \\
\hline Inoue et al. [48] & 10 & $2.9 \pm 28.0 \%$ per year & $1,617 \pm 553$ \\
\hline Langenbucher et al. [47] & 2 & $71 \pm 12 \%$ compared with the initial number & $872 \pm 348$ \\
\hline Patel et al. [49] & 15 & & $695 \pm 113.6$ \\
\hline Zadok et al. [9] & 13.3 & & \\
\hline ECD endothelial cell density & & & \\
\hline
\end{tabular}


was evaluated after an average of 5.4 post-operative years with a minimum cell density of $1,100 \mathrm{cell} / \mathrm{mm}^{2}$. We observed no higher endothelial cell loss associated with higher initial endothelial cell number.

Human corneal endothelial cells were first examined and photographed in vivo with a specular microscope in 1968 [22]. Age-related and post-operative changes, such as increasing pleomorphism, polymegethism, decreasing cell density in corneal endothelial layer and increasing corneal thickness, have already been observed and well described in several studies [5, 7, 21-26]. Bourne [27] reported that the markedly enlarged endothelial cells in long-term corneal transplants have a reduced ability to keep cornea clear. Møller-Pedersen [25] described higher rate of cell loss in younger groups. His data about annual loss of $2.9 \%$ up to 14 years and $0.3 \%$ after 14 years postoperatively are lower than those in our study.

Several studies report a rate of $0.3-0.6 \%$ endothelial cell loss per year in normal corneas [2, 21, 24, 28-30]. After intraocular surgery, the rate of endothelial cell loss is increased $[2,31,32]$. After cataract surgery, the rate of ECD loss increases up to $2.5 \%$ per year during the first 10 years [33]. ECD decreasing is also known after posterior lamellar keratoplasty [7, 8]. Endothelial cell loss was more rapid after PKP than that of post-cataract patients in 5-10 post-operative years, although donor corneas obviously lose endothelial cells during preservation and transplantation procedure. Decreasing is generally observed in studies [34-37], but there is one reported case finding with no endothelial cell decrease after PKP [6]. Relatively few attempts have been made to study at least 5-year graft survival with at least 500 eyes $[4,5,7$, 38].

Endothelial cell loss after surgeries like PKP is mostly described with bi-exponential model with two periods: a rapid period in the 1st post-operative year and a slow one that persists for years [8, 16, 25, 33, 34, 36, 38-42]. In the first 2 post-operative years after PKP, an overall endothelial cell loss of $33 \%$ has been reported [43], similarly to our data of $\mathbf{1 5 . 8 \%}$ per year in that period. After these 2 initial years, ECD continues to decrease with a three to seven times higher rate than normally for up to 20 years after surgery $[7,8,35,36,42]$. Density resuction is at an average of $50-65 \%$ [2, 44], 10 years after keratoplasty. After PKP, the rapid period of endothelial cell loss is longer than after cataract surgery, but after 4 years this difference becomes negligible [16]. Another model for describing cell loss called the mono-exponential model underestimates early cell loss and overestimates longterm cell loss when applied for long-term data interpretation [38].

ECD decreases with age so donor age can be a significant risk factor for late endothelial donor failure [29]. Only donor corneas with an ECD of at least 2,000 cells/ $\mathrm{mm}^{2}$ were suitable for PKP in our study. One of the researchers observed higher endothelial cell loss in grafts for keratoconus [45]; others reported higher ECD loss after PKP for Fuchs' dystrophy or corneal oedema $[46,47]$. Opposing studies, similar to our data, found no significant correlation between endothelial cell loss and recipient or donor age or pre-operative diagnosis, even in the long-term period $[2,6,9,32,35,48]$.

In one of his publications, Kus reported an ECD of $808 \pm 194$ cells $/ \mathrm{mm}^{2}$ with a mean thickness of $608 \pm 75 \mu \mathrm{m}$ correlated with neither thickness nor follow-up interval [6]. The coefficient of variation of cell area was approximately 0.29 in the first 5 years in Ing's study, which was smaller than corresponding data in our study [5].The corneal thickness was between 0.54 and $0.57 \mathrm{~mm}$ in the first 5 post-operative years [5], which is similar to our data.

In conclusion, the process of endothelial cell loss is highly accelerated after PKP. There are relatively few studies with more than 5 years post-operative donor endothelial data as in our study $[2,4-6,9,29,44$,$] . The$ rate of loss was similar in different pre-operative causative lesions and did not differ in consideration of preoperative donor endothelial cell number, donor or recipient's age.

\section{Financial interest}

Beata Kettesy, Gabor Nemeth, Adam Kemeny-Beke, Andras Berta and Laszlo Modis Jr., have no financial or proprietary interests in any of the mentioned device/ instruments used in this study.

\section{Conflict of interest}

The authors declare that there are no actual or potential conflicts of interest in relation to this article.

\section{References}

1. Laibson PR, Rapuano CJ. 100-year review of cornea. Ophthalmology. 1996;103(8):17-28.

2. Linn JG Jr, Stuart JC, Warnicki JW, Sinclair RA, Marsh GM. Endothelial morphology in long-term keratoconus corneal transplants. Ophthalmology. 1981;88:761-70.

3. Price FW Jr, Whitson WE, Collins KS, Marks RG. Five-year corneal graft survival. A large, single-center patient cohort. Arch Ophthalmol. 1993;111:799-805.

4. Vail A, Gore SM, Bradley BA, Easty DL, Rogers CA. Corneal transplantation in the United Kingdom and Republic of Ireland. Br J Ophthalmol. 1993;77:650-6.

5. Ing JJ, Ing HH, Nelson LR, Hodge DO, Bourne WM. Ten year postoperative results of penetrating keratoplasty. Ophthalmology. 1998;105:1855-65.

6. Kus MM, Seitz B, Langenbucher A, Naumann GO. Endothelium and pachymetry of clear corneal grafts 15 to 33 years after penetrating keratoplasty. Am J Ophthalmol. 1999;127:600-2.

7. Patel NP, Kim T, Rapuano CJ, Cohen EJ, Laibson PR. Indications for and outcomes of repeat penetrating keratoplasty, 1989-1995. Ophthalmology. 2000;107:719-24.

8. Bourne WM. Cellular changes in transplanted human corneas. Cornea. 2001;20:560-9.

9. Zadok D, Schwarts S, Marcovich A, et al. Penetrating keratoplasty for keratoconus: long-term results. Cornea. 2005;20:959-61.

10. Williams KA, Muehlberg SM, Lewis RF, Coster DJ. Longterm outcome in corneal allotransplantation. The Australian Corneal Graft Registry. Transplant Proc. 1997;29:983. 
11. Williams KA, Lowe M, Bartlett C, Kelly TL, Coster DJ. Risk factors for human corneal graft failure within the Australian corneal graft registry. Transplantation. 2008;86:1720-4.

12. Thompson RW Jr, Price MO, Bowers PJ, Price FW Jr. Longterm graft survival after penetrating keratoplasty. Ophthalmology. 1993;110:1396-402.

13. Kirkness CM, Ficker LA, Steele AD, Rice NS. The success of penetrating keratoplasty for keratoconus. Eye. 1990;4:673-88.

14. Bigar F. Specular microscopy of the corneal endothelium: optical solutions and clinical results. DevOphthalmol. 1982;6:1-94.

15. Mishima S. Clinical investigations on the corneal endothelium-XXXVIII Edward Jackson Memorial Lecture. Am J Ophthalmol. 1982;93:1-29.

16. Armitage WJ, Dick AD, Bourne WM. Predicting endothelial cell loss and long-term corneal graft survival. Invest Ophthalmol Vis Sci. 2003;44:3326-31.

17. Muraine M, Sanchez C, Watt L, Retout A., Brasseur G. Long-term results of penetrating keratoplasty. A 10-yearplus retrospective study. Graefes Arch Clin Exp Ophthalmol. 2003;241:571-6.

18. Hoffer KJ. Corneal decompensation after corneal endothelium cell count. Am J Ophthalmol. 1979;87:252-3.

19. Olsen T, Eriksen JS. Corneal thickness and endothelial damage after intraocular lens implantation. Acta Ophthalmol (Copenh). 1980;58:773-86.

20. Waring GO 3rd, Bourne WM, Edelhauser HF, Kenyon KR. The corneal endothelium: normal and pathologic structure and function. Ophthalmology. 1982;89:531-90.

21. Yee RW, Matsuda M, Schultz RO, Edelhauser HF. Changes in the normal corneal endothelial cellular pattern as function of age. Curr Eye Res. 1985;4:671-8.

22. Maurice DM. Cellular membrane activity in the corneal endothelium of the eye. Experientia. 1968;24:1094-5.

23. Laule A, Cable MK, Hoffman CE, Hanna C. Endothelial cell population changes of human cornea during life. Arch Ophthalmol. 1978;96:2031-5.

24. Carlson H, Bourne WM, McLaren JW, Brubaker RF. Variations in human endothelial morphology and permeability to fluorescein with age. Exp Eye Res. 1988;47:27-41.

25. Møller-Pedersen T. Comparative study of human corneal keratocyte and endothelial cell density during aging. Cornea. 1997;16:333-8.

26. Iwashita M. Specular microscopic study of cases treated with penetrating keratoplasty: morphological changes in the endothelium. Nippon Ganka Gakkai Zasshi. 1998;92:1130-8.

27. Bourne WM. Functional measurements on the enlarged endothelial cells of corneal transplants. Trans Am Ophthalmol Soc. 1995; 93:65-82.

28. Hoffer KJ, Kraff MC. Normal endothelial cell count range. Ophthalmology. 1980;87:861-6.

29. Bourne WM, Nelson LR, Hodge DO. Central corneal endothelial cell changes over a ten-year period. Invest Ophthalmol Vis Sci. 1997;38:779-82.

30. Rao SK, RanjanSen P, Fogla R, Gangadharan S, Padmanabhan P, Badrinath SS.Corneal endothelial cell density and morphology in normal Indian eyes. Cornea. 2000;19:820-3.

31. Liesegang TJ, Bourne WM, Ilstrup DM. Short- and longterm endothelial cell loss associated with cataract extraction and intraocular lens implantation. Am J Ophthalmol. 1984;97:32-9.
32. Ambrose VM, Walters RF, Batterbury M, Spalton DJ, McGill JI. Long-term endothelial cell loss and breakdown of the blood-aqueous barrier in cataract surgery. J Cataract Refract Surg. 1991;17:622-7.

33. Bourne WM, Nelson LR, Hodge DO. Continued endothelial cell loss ten years after lens implantation. Ophthalmology. 1994;101:1014-23.

34. Bourne WM. One-year observation of transplanted human corneal endothelium. Ophthalmology. 1980;87:673-9.

35. Abbott RL, Fine M, Guillet E. Long-term changes in corneal endothelium following penetrating keratoplasty. A specular microscopic study. Ophthalmology. 1983;90:676-85.

36. Obata H, Murao M, Miyata K, Sawa M. Corneal endothelial cell damage in penetrating keratoplasty. Nippon Ganka Gakkai Zasshi. 1992;96:346-51.

37. Bourne WM, Hodge DO, Nelson LR. Corneal endothelium five years after transplantation. Am J Ophthalmol. 1994;118:185-96.

38. Redmond RM, Armitage WJ, Whittle J, Moss SJ, Easty DL. Longterm survival of endothelium following transplantation of corneas stored by organ culture. Br J Ophthalmol. 1992;76:479-81.

39. Zacks CM, Abbott RL, Fine M. Long-term changes in corneal endothelium after keratoplasty: a follow-up study. Cornea. 1990;9:92-7.

40. Langenbucher A, Nguyen NX, Kus MM, Blüthner K, Küchle M, Seitz B. Regression analysis of corneal endothelium after nonmechanical penetrating keratoplasty. Klin Monatsbl Augenheilkd. 2000;216:393-9.

41. Böhringer D, Reinhard T, Godehardt E, Sundmacher R. Regression analysis of idiopathic endothelial cell loss after penetrating normal risk keratoplasty: basic principles for long-term analysis of endothelial risk factors in a retrospective clinical study. Klin Monatsbl Augenheilkd. 2001;218:412-7.

42. Böhringer D, Reinhard T, Spelsberg H, Sundmacher R. Influencing factors on chronic endothelial cell loss characterised in a homogenous group of patients. Br J Ophthalmol. 2002;86:35-8.

43. Culbertson WW, Abbott RL, Forster RK. Endothelial cell loss in penetrating keratoplasty. Ophthalmology. 1982;89:600-4.

44. Nishimura JK, Hodge DO, Bourne WM. Initial endothelial cell density and chronic endothelial cell loss rate in corneal transplants with late endothelial failure. Ophthalmology. 1999;106:1962-5.

45. Patel SV, Hodge DO, Bourne WM. Corneal endothelium and postoperative outcomes 15 years after penetrating keratoplasty. Am J Ophthalmol. 2005;139:311-9.

46. Reinhard T, Bohringer D, Huschen D, Sundmacher R. Chronic endothelial cell loss of the graft after penetrating keratoplasty: influence of endothelial cell migration from graft to host. Klin Monatsbl Augenheild. 2002;219:410-6.

47. Langenbucher A, Seitz B, Nguyen NX, Naumann GO. Corneal endothelial cell loss after nonmechanical penetrating keratoplasty depends on diagnosis: a regression analysis. Graefes Arch Clin Exp Ophthalmol. 2002;240:387-92.

48. Inoue K, Kimura C, Amano S, Oshika T, Tsuru T. Corneal endothelial cell changes twenty years after penetrating keratoplasty. Jpn J Ophthalmol. 2002;46:189-92.

49. Patel SV, Hodge DO, Bourne WM. Corneal endothelium and postoperative outcomes 15 years after penetrating keratoplasty. Trans Am Ophthalmol Soc. 2004;102:57-65. 